пределах нормы. Наблюдается незначительное снижение тонуса сосудов распределения, что не является патологическим.

Ключевые слова: промышленность, мозговое кровообращение, экологически чистая зона, реоэнцефалография.

Pshybelskyi Vladimir. The Impact of Industry on Cerebral Blood Flow in Males. Analyzed and studied the features of cerebral blood flow in males who are engaged in industrial production and persons living in a relatively ecologically clean areas. A statistically different values of cerebral blood flow between the two groups studied. In the group of persons employed in industrial production observed statistically lower values of pulse blood filling period, a period of slow and diastolic blood filling index. Also in these individuals observed moderate asymmetry blood supply and venous drainage trouble impressive on both sides of the investigated area. In the group of persons ecologically clean areas mentioned indicators are within normal limits. There is a slight decrease in vascular tone distribution, which is not abnormal.

Key words: industry, cerebral blood flow, ecologically clean area, rheoencephalography.

Стаття надійшла до редколегії 20.09.2015 p.

УдК 612.6:371.72

\author{
Юрій Трофим'як, \\ Олена Дмитроца, \\ Світлана Швайко
}

\title{
Порівняльна характеристика фізичного розвитку молодших школярів залежно від місця проживання
}

Вивчено особливості фізичного розвитку школярів молодшого шкільного віку, які проживають у міській та сільській місцевостях. У результаті дослідження встановлено, що показники фізичного розвитку молодших школярів відповідали середньому рівню; серед обстежуваних із сільської місцевості найчастіше трапляються випадки з нормативними або підвищеними показниками рівня фізичного розвитку.

Ключові слова: фізичний розвиток, молодший шкільний вік, антропометричний показник, місце проживання.

Постановка наукової проблеми та її значення. Унікальний критерій здоров’я населення - фізичний розвиток, за ознаками якого можна простежити і глобальні зміни біології природи людини, і порівняно короткотривалі зміни в популяції $[1 ; 5 ; 8]$. Фізичний розвиток $\epsilon$ сукупністю морфологічних та функціональних властивостей організму, що характеризують процес його росту й розвитку. Указані характеристики залежать як від спадковості, так і від складного комплексу соціально-гігієнічних умов. Оскільки процеси росту та розвитку організму дитини шкільного віку $є$ незавершеними, то він чутливий до впливу змін у навколишньому середовищі (екологічних, соціально-побутових, економічних, географічних тощо) [3; 12].

Фізичний розвиток - один із провідних критеріїв оцінки стану здоров'я учнів, важливий і доступний для вимірювання, оцінки та інтеграції. Згідно з даними наукових джерел, постійних і єдиних стандартів антропометричних показників для всіх дітей бути не може, оскільки вони змінюються залежно від соціально-побутових та клімато-географічних умов життя. Важливим $\epsilon$ вивчення регіональних показників фізичного розвитку з їх регулярним оновленням кожні 5-7 років [3;5; 8; 15].

Комплексна оцінка фізичного розвитку дитини полягає у визначенні рівня фізичного розвитку (за довжиною тіла), гармонійності фізичного розвитку (за масою тіла, окружністю грудної клітини та показниками функціонального стану) $[6,12]$. Рівень фізичного розвитку відіграє особливу роль під час установленя стану здоров'я учнів, організм яких перебуває в стадії формування й через свою пластичність надзвичайно схильний як до позитивних, так і до негативних впливів факторів зовнішнього середовища. Тому показники фізичного розвитку відображають не лише стан здоров'я дітей i підлітків, а й соціально-економічні та соціально-гігієнічні умови їхнього життя, рівень і якість організації.

( Трофим’як Ю., Дмитроияа О., Швайко С., 2015 
Аналіз дослідження цісї проблеми. Гарантом підвищення кількості здорових дітей та підлітків $\epsilon$ гармонійний фізичний розвиток протягом усього дитинства. Здоров'я нації - показник цивілізованості держави, що відображає соціально-економічне становище суспільства. Відомо, що близько $75 \%$ захворювань у дорослих - наслідок умов життя в дитячому та молодому віці. Захворюваність і поширеність різноманітної патології серед дитячого населення в Україні залишаються високими за всіма основними класами хвороб $[4 ; 9 ; 13]$. Зміцнення здоров'я та підвищення рівня фізичної підготовленості не лише дітей, а й усіх категорій людей, вважається сьогодні однією з найбільш гострих проблем цивілізованих держав [7; 8]. Отже, питання формування здоров'я - це важлива складова частина комплексної оцінки стану здоров'я школярів.

Відомо про прискорення темпів фізичного розвитку дітей, що характеризується наявністю процесів акселерації на рівні цілих регіонів. Проте, за даними наукових джерел, відзначено тенденцію до зменшення кількості фізично здорових школярів як міської, так і сільської місцевості [3; 11]. Аналіз стану фізичного розвитку школярів України також показує, що учні з міста й села мають і спільні закономірності, і відмінності, які залежать від місця проживання $[11,13]$.

Дані літератури щодо фізичного розвитку міських і сільських школярів у різних регіонах України, зокрема з урахуванням особливостей довкілля, мають несистемний характер [11; 12]. Тому дослідження фізичного здоров'я школярів - актуальне.

Мета роботи - вивчення особливостей рівня фізичного розвитку дітей молодшого шкільного віку (семи, восьми та дев'яти років), котрі проживають у місті та сільській місцевості. Перед нами постало завдання - за основними антропометричними показниками визначити фізичний розвиток дітей молодшого шкільного віку, ураховуючи місце проживання.

Матеріали та методи дослідження. Дослідження проведено на 240 учнях молодшого шкільного віку, здорових, праворуких. Усіх обстежуваних розділили на дві групи: I - школярі, котрі мешкають у місті (120), II - діти із сільської місцевості (120). У межах кожної групи виокремили підгрупи (по 40 осіб) семи, восьми та дев'яти років, ураховуючи статевий аспект.

Оцінку фізичного розвитку проводили за даними росту (см), маси тіла (кг) й окружності грудної клітки (ОГК, см). Оцінювання фізичного розвитку школярів здійснювали за методами сигнальних відхилень від його середньостатичних показників (зріст, маса тіла, ОКГ), порівнюючи їх зі стандартами для кожної віково-статевої групи. За даними сигнальних відхилень будували профіль фізичного розвитку та визначали його рівень: низький, нижчий за середній, середній, вищий за середній, високий [6].

Під час обробки отриманих даних використовували методи варіаційної статистики з оцінкою t-критерію Стьюдента 3 визначенням середнього значення показника (M), величини середньої похибки $( \pm \mathrm{m})$, критерію достовірності Стьюдента $(\mathrm{t})$. Різницю між двома середніми величинами вважали достовірною при значеннях $\mathrm{p} \leq 0,05$

Виклад основного матеріалу й обгрунтування отриманих результатів дослідження. Аналіз основних антропометричних показників (ріст, вага, окружність грудної клітки), за якими визначали рівень фізичного розвитку учнів молодшого шкільного віку, ураховуючи місце проживання, дав підставу, щоб виявити такі особливості:

- Хлопці із сільської місцевості характеризувалися вищими показниками зросту відносно вікових норм, порівняно з однолітками з міської зони; ця закономірність особливо чітко проявляється з віком (табл. 1). У дівчаток за показниками зросту зафіксовано подібну тенденцію: із віком вони достовірно вищі в сільських обстежуваних (див. табл. 1). Потрібно відзначити, що хлопці й дівчата із міських шкіл характеризувалися зниженими показниками зросту, порівняно з віковими нормами. Статеві відмінності за показниками зросту виявлено для школярів із міської зони: дівчатка семи й восьми років характеризувалися достовірно нижчими показниками зросту.

- Дані маси тіла обстежуваних більшою мірою наближалися до вікових норм у школярів із сільської місцевості, незалежно від віку та статі (див. табл. 1). Дівчата із міської зони характеризувалися достовірно нижчими показниками маси тіла в усіх вікових групах; у хлопців достовірні відмінності виявлено лише в 9-річному віці. Статеві відмінності за масою більш виражені в сім та вісім років; проте достовірних відмінностей не виявлено.

• На фізичний розвиток указує й окружність грудної клітки (ОГК), за показниками якої незначно переважали хлопці з міста (див. табл. 1), тоді як у дівчаток, котрі проживають у сільській місцевості, 
ОГК є вищою, порівняно з іншою групою обстежуваних; така відмінність особливо чітко проявляється у 8-річному віці. Зафіксовано й статеві відмінності: в обстежуваних із міської зони хлопці за вказаним показником переважали дівчат; в іншій групі такої особливості не виявлено.

Важливо зауважити: хлопці молодшого шкільного віку обох груп перевищували за зростом дівчат, незалежно від віку обстежуваних. Ця особливість відповідає віковим нормам [10; 12].

Ураховуючи дані зросту, маси тіла й ОГК, визначали рівень фізичного розвитку молодших школярів, який характеризувався такими особливостями:

Таблиия 1

Показники антропометричних вимірювань обстежуваних для визначення фізичного розвитку (ФР) та його оцінка $(M \pm m)$

\begin{tabular}{|c|c|c|c|c|c|c|}
\hline \multirow{2}{*}{$\begin{array}{l}\text { Вік, } \\
\text { років }\end{array}$} & \multicolumn{3}{|c|}{ Хлопці $(n=20)$} & \multicolumn{3}{|c|}{ Дівчата $(n=20)$} \\
\hline & $\begin{array}{c}\text { рict, } \\
c M\end{array}$ & $\begin{array}{c}\text { вага, } \\
\kappa 2\end{array}$ & $\begin{array}{c}\text { ОГК, } \\
c M\end{array}$ & $\begin{array}{c}\text { pict, } \\
c \boldsymbol{c M}\end{array}$ & $\begin{array}{c}\text { вага, } \\
c \text { M }\end{array}$ & $\begin{array}{c}\text { ОГК, } \\
c, M\end{array}$ \\
\hline \multirow{8}{*}{$\begin{array}{c}7 \\
\text { років }\end{array}$} & \multicolumn{6}{|c|}{ Нормативні значення } \\
\hline & $126,30 \pm 0,39$ & $\begin{array}{c}25,99 \pm \\
0,30\end{array}$ & $\begin{array}{c}61,82 \pm \\
0,28\end{array}$ & $\begin{array}{c}124,41 \pm \\
0,36\end{array}$ & $\begin{array}{c}24,16 \pm \\
0,30 \\
\end{array}$ & $\begin{array}{c}60,11 \pm \\
0,27\end{array}$ \\
\hline & \multicolumn{6}{|c|}{ Обстежувані міської зони } \\
\hline & $\begin{array}{c}122,55 \pm \\
1,47\end{array}$ & $\begin{array}{c}23,48 \pm \\
1,09\end{array}$ & $\begin{array}{l}62,6 \pm \\
1,03\end{array}$ & $\begin{array}{c}114,73 \pm \\
1,55\end{array}$ & $\begin{array}{c}21,42 \pm \\
0,96\end{array}$ & $\begin{array}{c}60,35 \pm \\
0,96\end{array}$ \\
\hline & \multicolumn{3}{|c|}{ ФР - середній } & \multicolumn{3}{|c|}{ ФР - середній } \\
\hline & \multicolumn{6}{|c|}{ Обстежуувані аграрної зони } \\
\hline & $\begin{array}{c}125,55 \pm \\
1,81\end{array}$ & $\begin{array}{c}25,27 \pm \\
1,24\end{array}$ & $\begin{array}{c}60,1 \pm \\
1,14\end{array}$ & $\begin{array}{c}125,4 \pm \\
1,85^{*}\end{array}$ & $\begin{array}{c}27,22 \pm \\
1,29^{*}\end{array}$ & $\begin{array}{c}60,25 \pm \\
0,86\end{array}$ \\
\hline & \multicolumn{3}{|c|}{ ФР - середній } & \multicolumn{3}{|c|}{ ФР - середній } \\
\hline \multirow{8}{*}{$\begin{array}{c}8 \\
\text { років }\end{array}$} & \multicolumn{6}{|c|}{ Нормативні значення } \\
\hline & $\begin{array}{l}128,93 \pm \\
0,43\end{array}$ & $\begin{array}{l}27,22 \pm \\
0,32\end{array}$ & $\begin{array}{l}62,53 \pm \\
0,34\end{array}$ & $127,99 \pm 0,44$ & $\begin{array}{c}26,61 \pm \\
0,35 \\
\end{array}$ & $\begin{array}{l}61,27 \pm \\
0,33\end{array}$ \\
\hline & \multicolumn{6}{|c|}{ Обстежувані міської зони } \\
\hline & $\begin{array}{c}122,1 \pm \\
1,39\end{array}$ & $\begin{array}{c}23,36 \pm \\
1,22\end{array}$ & $\begin{array}{c}62,35 \pm \\
1,04\end{array}$ & $\begin{array}{c}117,5 \pm \\
1,15\end{array}$ & $\begin{array}{c}20,58 \pm \\
0,64\end{array}$ & $\begin{array}{c}58,75 \pm \\
0,71\end{array}$ \\
\hline & \multicolumn{3}{|c|}{ ФР - нижчий за середній } & \multicolumn{3}{|c|}{ ФР - низький } \\
\hline & \multicolumn{6}{|c|}{ Обстежувані аграрної зони } \\
\hline & $\begin{array}{c}128,2 \pm \\
1,89^{*}\end{array}$ & $\begin{array}{c}26,65 \pm \\
1,37\end{array}$ & $\begin{array}{c}62,75 \pm \\
1,35\end{array}$ & $\begin{array}{c}131,3 \pm \\
2,03^{*}\end{array}$ & $\begin{array}{l}27,8 \pm \\
1,16^{*}\end{array}$ & $\begin{array}{c}63,25 \pm \\
0,88^{*}\end{array}$ \\
\hline & & $\overline{\mathrm{DP}}$ - середн & & & $\mathrm{P}$ - середі & \\
\hline \multirow{8}{*}{$\begin{array}{c}9 \\
\text { років }\end{array}$} & \multicolumn{6}{|c|}{ Нормативні значення } \\
\hline & $\begin{array}{l}135,96 \pm \\
0,50\end{array}$ & $31,55 \pm 0,41$ & $\begin{array}{l}64,57 \pm \\
0,38\end{array}$ & $134,72 \pm 0,46$ & $\begin{array}{l}30,70 \pm \\
0,40\end{array}$ & $\begin{array}{l}63,97 \pm \\
0,34\end{array}$ \\
\hline & \multicolumn{6}{|c|}{ Обстежувані міськой зони } \\
\hline & $\begin{array}{c}128,55 \pm \\
1,671 \\
\end{array}$ & $\begin{array}{c}26,03 \pm \\
1,47 \\
\end{array}$ & $\begin{array}{c}68,3 \pm \\
1,89 \\
\end{array}$ & $\begin{array}{c}126,25 \pm \\
1,34 \\
\end{array}$ & $\begin{array}{c}25,53 \pm \\
1,31 \\
\end{array}$ & $\begin{array}{c}65,3 \pm \\
1,01 \\
\end{array}$ \\
\hline & \multicolumn{3}{|c|}{ ФР - нижчий за середній } & \multicolumn{3}{|c|}{ ФР - нижчий за середній } \\
\hline & \multicolumn{6}{|c|}{ Обстежувані аграрної зони } \\
\hline & $\begin{array}{c}140,1 \pm \\
1,25^{*}\end{array}$ & $\begin{array}{c}31,8 \pm \\
1,3 *\end{array}$ & $\begin{array}{c}67,35 \pm \\
0,6\end{array}$ & $\begin{array}{c}138,15 \pm \\
1,82^{*}\end{array}$ & $\begin{array}{c}31,85 \pm \\
1,82^{*}\end{array}$ & $\begin{array}{c}67,45 \pm \\
1,34\end{array}$ \\
\hline & & DP - середн & & & - серв & \\
\hline
\end{tabular}

Примітка. Знак «*» указує на достовірно вищий показник у межах однієї вікової групи.

- Серед 7-річок, котрі проживають у місті, в обох статевих групах осіб із високим рівнем фізичного розвитку не виявлено (рис. $1 ; 2$ ), тоді як у хлопців із сільської зони в 5 \% випадків 
зафіксовано високий фізичний розвиток. Проте частка осіб із нижчим за середній рівнем фізичного розвитку вищою виявилась у хлопців із міської зони. У 7-річних дівчаток частка осіб із фізичним розвитком, що відповідає низькому та нижчому за середній рівням, вища в міських школярок.

- У 8-річних школярів зафіксовано меншу частку осіб із низьким фізичним розвитком серед школярів із сільської місцевості, незалежно від статі (див. рис. 1; 2). Особливо високою часткою 3 низьким рівнем фізичного розвитку характеризувалися дівчата із міської зони. Високий рівень фізичного розвитку найчастіше простежували серед хлопчиків із сільської місцевості.
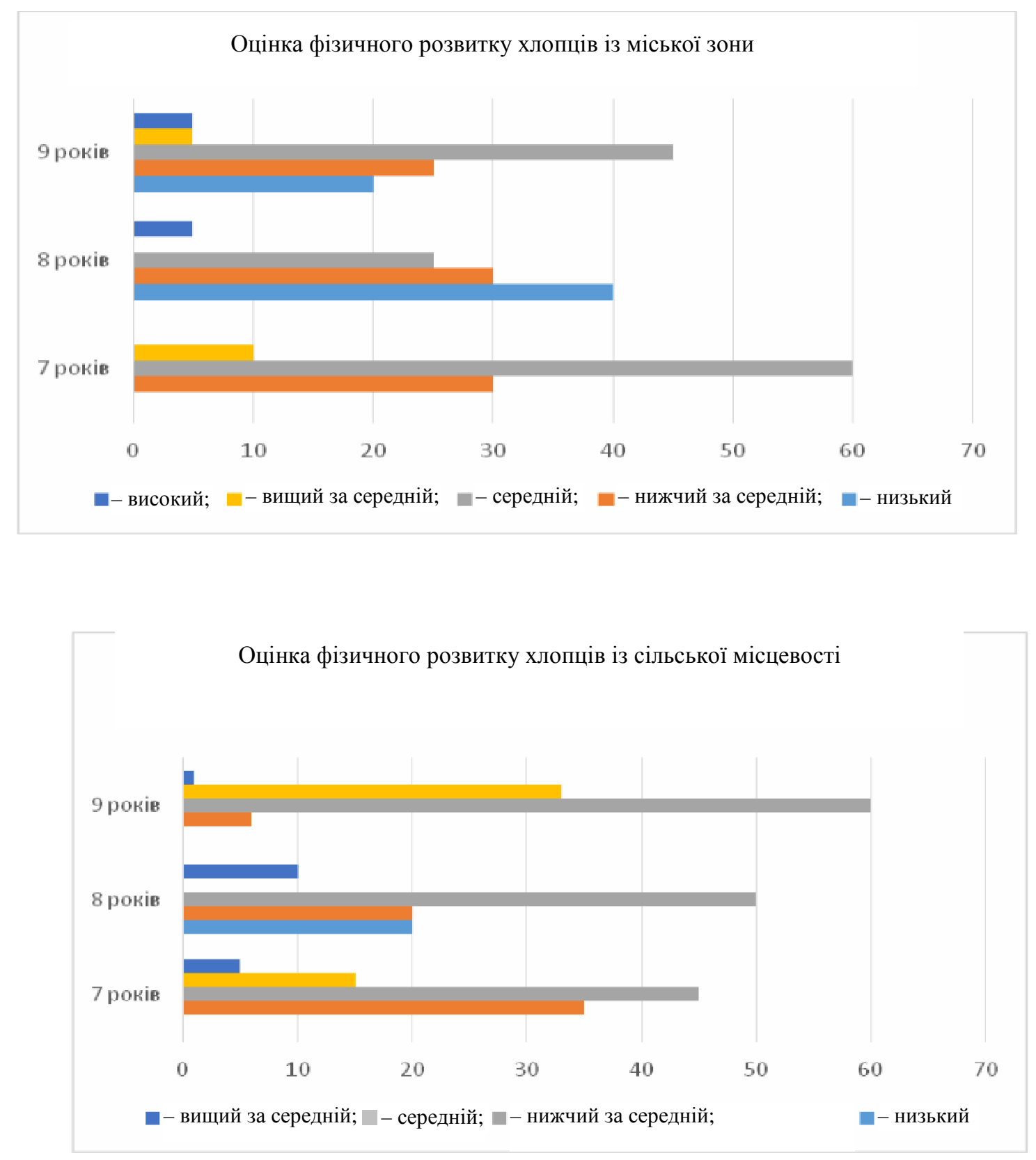

Рис. 1. Розподіл за показниками фізичного розвитку хлопиів міської та сільської місцевостей 


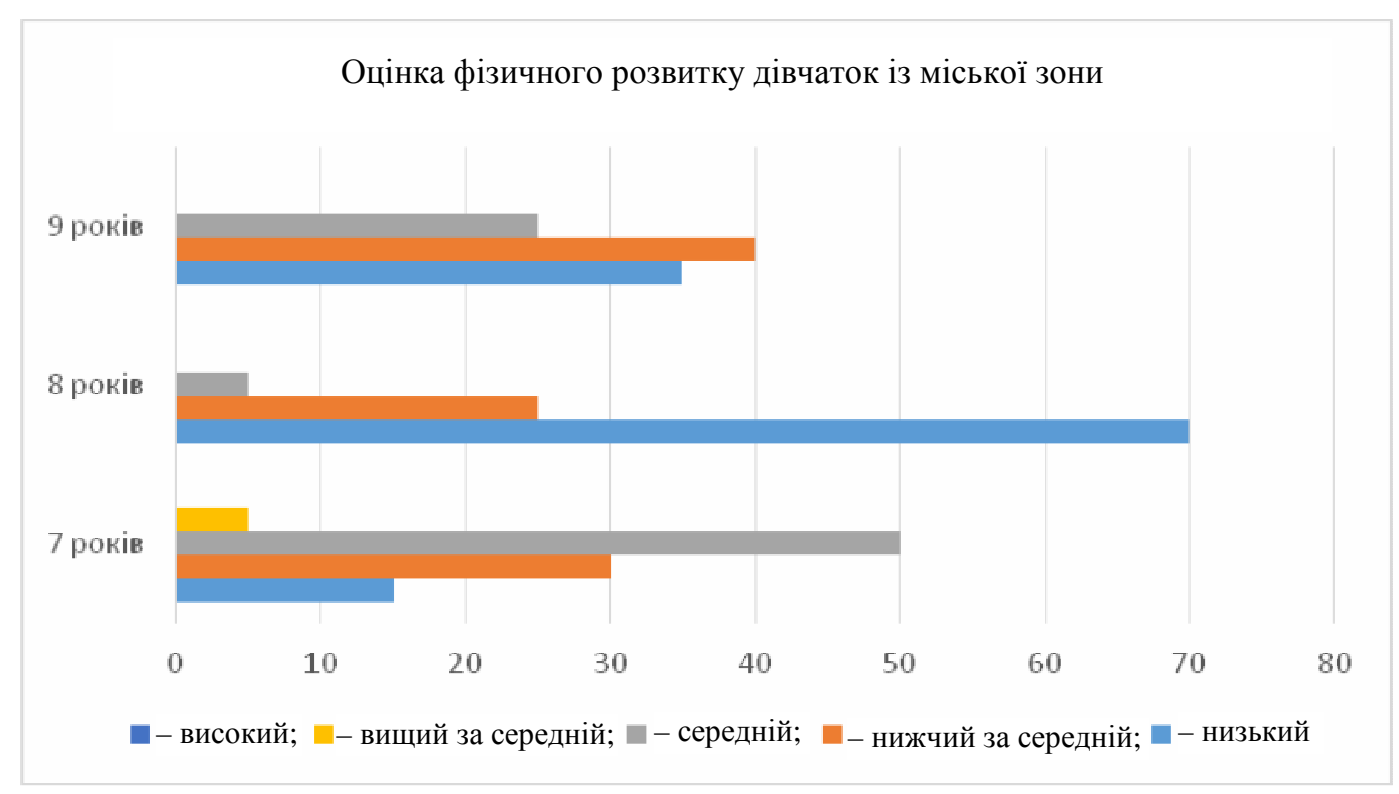

Оцінка фізичного розвитку дівчаток із сільської місцевості

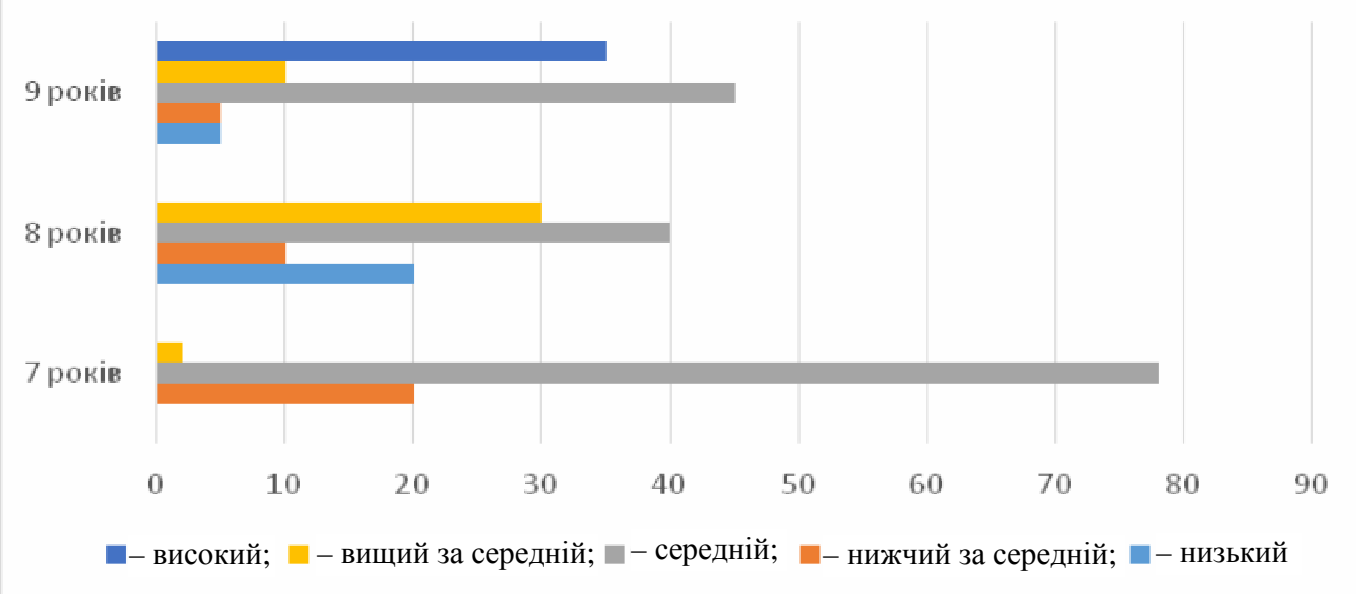

Рис. 2. Розподіл за показниками фізичного розвитку дівчаток із міської (I) та сільської місцевостей (II)

У школярів 9-річного віку високий рівень фізичного розвитку простежено в 5 \% хлопців із міської зони та $35 \%$ дівчат із сільської (рис. 1; 2). Загалом, у дівчаток цього віку знижений фізичний розвиток, а саме низький і нижчий за середній більшою мірою проявлявся в міській зоні.

Отже, показники фізичного розвитку молодших школярів коливалися від нижчого за середній до середнього рівня та певним чином залежали від місця проживання. У групі обстежуваних із сільської зони усереднені дані фізичного розвитку відповідали середньому рівню, незалежно від статі й віку. Для цієї групи обстежуваних характерні випадки з нормативними або підвищеними показниками рівня фізичного розвитку.

У жителів із міської зони усереднені показники фізичного розвитку відповідають середньому рівню у 8-річному віці в обох статевих групах, тоді як у вісім та дев'ять років за усередненими значеннями рівень фізичного розвитку відповідає основному, нижчому за середній рівням (у дівчат восьми років - низькому). Цікаво відзначити, що в 7-річному віці не виявлено осіб із високим рівнем фізичного розвитку серед дітей iз міської зони; із низьким рівнем не виявлено осіб серед обстежуваних обох груп. У 8- та 9-річному віці високий рівень фізичного розвитку трапляється серед хлопчиків із деякою перевагою в сільській місцевості; серед дівчат такої особливості не простежено. У дівчаток 8- та 9-ти років більше випадків із низьким рівнем фізичного розвитку, незалежно від місця проживання. Потрібно зазначити, що з віком чіткіше проявляються 
відхилення від нормативних значень основних антропометричних показників. Ця особливість більше виражена в міських школярів, у яких рівень фізичного розвитку нижчий, порівняно із сільськими. Таку закономірність висвітлено в наукових джерелах [7, 11].

Результати наших досліджень зіставлено з даними інших наукових джерел і простежено, що показники фізичного розвитку молодших школярів мають відхилення. При цьому потрібно відначити: довжина й маса тіла, окружність грудної клітки перебувають у межах вікових норм. Показники фізичного розвитку школярів зростають нерівномірно, що обумовлено фізіологічними механізмами препубертатного періоду [2; 8; 12]. Нами зафіксовано перевагу сільських обстежуваних щодо даних фізичного розвитку. Цю особливість можна пов' язати з характеристиками соціально-економічних умов життя в сільській місцевості й багатьма іншими причинами. Можливе припущення, як і за даними наукових джерел, що сільські школярі (особливо хлопці) ведуть активніший руховий режим і піддаються в повсякденному побуті значним фізичним навантаження, що негативно впливає на темпи росту $[7 ; 11]$.

Отже, незважаючи на більшість однонаправлених показників росту школярів із села й міста при обох аналізах, уважаємо, що доцільно проводити їх порівняння з місцевими стандартами. Нині потрібно вважати, що термін використання місцевих стандартів вичерпано, у зв'язку з чим і постає гостра потреба в їх регулярному обновленні.

Висновки та перспективи подальшого дослідження. Основні антропометричні показники школярів перебували в межах вікових норм і є вищими в обстежуваних із сільської місцевості; ця особливість чітко проявляється до завершення молодшого шкільного віку. Показники фізичного розвитку молодших школярів відповідали середньому рівню; серед обстежуваних із сільської місцевості найбільше випадків із нормативними або підвищеними показниками рівня фізичного розвитку.

У перспективі планується проводити дослідження динаміки рівня фізичного здоров'я школярів, котрі проживають у різних регіонах Волинської області; при виявленні відхилень показників фізичного розвитку здійснювати комплексне обстеження дітей на предмет раннього виявлення соматичних захворювань; на регіональному рівні - розробити місцеві стандарти антропометричних показників школярів.

\section{Джерела та література}

1. Билецкая В. В. Силовые способности детей младшего школьного возраста и способы их оценки / В. В. Билецкая // Физическое воспитание студентов : науч. журн. - Харьков : ХООНОКУ-ХГАДИ, 2010. - № 1. - C. 3-7.

2. Богдановська Н. В. Адаптивні можливості серцево-судинної системи дітей шкільного віку та шляхи їх оптимізації : автореф. дис. ... канд. наук з фіз. вих. і спорту : спец. 24.00.02 «Фізична культура, фізичне виховання різних груп населення» / Н. М. Гончарова. - К., 2009. - 20 с.

3. Величко В. О. Фізичний розвиток дітей шкільного віку півдня України / В. О. Величко, І. Л. Бабій // Здоров’я дитини. - 2008. - № 3. - С. 62-64.

4. Гозак С. В. Вплив чинників навчального процесу на показники здоров'я школярів / С. В. Гозак // Довкілля та здоров’я. - 2012. - № 3. - С. 17-20.

5. Даниленко Г. М. Методичні проблеми формування, збереження та зміцнення здоров'я школярів / Г. М. Даниленко // Лікарська справа. - 2004. - №1. - С. 128-131.

6. Даценко I. І. Гігієна дітей і підлітків : підручник / I. І. Даценко, М. Б. Шегедин, Ю. І. Шашков. - К. : Медицина, 2006. - 304 с.

7. Дудіна О. О. Ситуаційний аналіз стану охорони здоров'я дітей та підлітків в Україні. Забезпечення принципу соціальної справедливості відносно здоров'я дітей та підлітків / О. О. Дудіна, Г. О. Слабкий, Р. О. Моїсеєнко та ін. // Вісник соціальної гігієни і організації охорони здоров'я України. - 2008. № 2. - C. 8-19.

8. Корнєв Н. В. Здоров'я школярів, сьогодення та проблеми на перспективу / Н. В. Корнєв, Г. М. Даниленко // Охорона здоров’я України. - 2003. - № 1. - С. 49-54.

9. Малютина М. А. Сравнительная характеристика валеологических составляющих качества жизни подростков города и села / М. А. Малютина, А. Н. Корденко // Физическая культура и здоровье. 2009. - № 6. - С. 72-74.

10. Мизюк М. М. Середні показники основних показників фізичного та біологічного розвитку дітей початкової школи прикарпатського регіону : метод. рек. / М. М. Мизюк, О. В. Тимощук, 3. Б. Суслик. - Київ : Івано-Франківськ : Вид-во Івано-Франківського держ. мед. ун-ту, 2006. - 56 с.

11. Сенаторова Г. С. Порівняльна характеристика фізичного розвитку дітей шкільного віку, що мешкають у місті та сільській місцевості / Г. С. Сенаторова, Л. Г. Тельнова, І. С. Дриль, М. О. Гладков, І. М. Гладкова // Современная педиатрия. - 2013. - № 8 (56). - С. 154-157. 
12. Сисоєнко Н. В. Стан здоров’я та особливості фізичного розвитку школярів 6-17 років, які навчались в загальноосвітніх закладах різних типів / Н. В. Сисоєнко // Вісник Черкаського університету. - 2010. Вип. 180. - С. 97-105.

13. Система профілактично-оздоровчих заходів з підготовки дітей старшого дошкільного віку до навчання у загальноосвітніх навчальних закладах : метод. рек. / [Н. С. Полька, І. О. Калиниченко, С. В. Гозак та ін.]. - К. : ДУ «Інститут гігієни та медичної екології ім. О. М. Марзєєва НАМН України», 2013. - 51 с.

14. Тяжка О. В. Сучасні особливості стану здоров'я дітей молодшого та середнього шкільного віку м. Києва / О. В. Тяжка, Л. М. Казакова, О. А. Строй // Клінічна педіатрія. - 2011. - № 4. - С. 41-44.

15. Lobstein T. Obesity in children / T. Lobstein // BMJ. - 2008. - Vol. 337. - P. 669.

Трохимьяк Юрий, Дмитроца Елена, Швайко Светлана. Сравнительная характеристика физического развития младших школьников в зависимости от места жительства. Изучаются особенности физического развития школьников, которые проживают в городской и сельской местностях. В результате исследования установлено, что показатели физического развития младших школьников отвечали среднему уровню, среди исследуемых сельськой местности чаще всего наблюдают случаи с нормативными или повышеными показателями уровня физического развития.

Ключевые слова: физическое развитие, младший школьный возраст, антронометрический показатель, место проживания.

Trofymiak Yurii, Dmytrotsa Olena, Shvayko Svitlana. Comparative Characteristics of Physical Development of Junior Schoolchildren, Depending on Your Place of Residence. The studied features of physical development in schoolchildren of primary school age living in urban and rural areas. The study found that indicators of physical development of Junior schoolchildren corresponded to the average level, among the surveyed rural areas to a greater extent meet the case of normative or elevated level of physical development.

Key words: physical development, primary school age, anthropometric index, place of residence.

Стаття надійшла до редколегії 10.09.2015 p.

УДК 616.24-002.5-085

\section{Любов Цеп'юк, Анастасія Марчук, Ольга Абрамчук}

\section{Аналіз легеневого матеріалу хворих на туберкульоз чоловіків Рівненської області}

Проаналізовано особливості мокроти хворих на туберкульоз чоловіків у Рівненській області, котрі перебували на стаціонарному лікуванні в Рівненському ОТД. У загальному аналізі мокроти при різних формах туберкульозного процесу виявлено різні елементи залежно від форми патологічного процесу. У всіх пацієнтів вивчали симптоми інтоксикації та бактеріовиділення. Показано, що на момент госпіталізації бактеріовиділення виявлено в 34 осіб із трьох досліджуваних груп, це свідчить про відкриту форму туберкульозного процесу.

Ключові слова: туберкульоз, інтоксикація, бактеріовиділення, патологічний процес, бронхіальний епітелій, альвеолярні макрофаги, еластичні волокна.

Постановка наукової проблеми та її значення. Нині туберкульоз - одна 3 найпоширеніших у світі інфекційних хвороб, яка посідає перше місце за смертністю людей від інфекційної патології [11]. Туберкульоз експертами ВОО3 проголошено глобальною небезпекою. Протягом останніх десятиріч у всьому світі й в Україні різко погіршується епідеміологічна ситуація з туберкульозу [3, 9]. Дедалі частіше спостерігають гостропрогресуючі, важкопротікаючі, а інколи й невиліковні форми туберкульозу. Найбільше занепокоєння викликають хворі, які активно виділяють мікобактерії туберкульозу в навколишнє середовище й зростання кількості форм зі зміненими біологічними особливостями. Близько 20-25 \% хворих упродовж року не виліковуються та поповнюють контингент із хронічними формами туберкульозу легень. На фоні неухильного зростання захворюваності й смертності від цієї недуги все більш актуальним стає питання своєчасного виявлення хвороби та ефективної боротьби з їі збудником $[1,2]$. У зв’язку з цим подальше

(С Цеп’юк Л., Марчук А., Абрамчук О., 2015 